\title{
PRINCIPLE ON THE LAND REGISTER IN THE INTERPRETATION OF JURISPRUDENCE
}

\section{Hamid Mutapčić ${ }^{1}$}

Faculty of Law, University of Tuzla

\author{
Original scientific paper
}

Received: 17.01.2016

UDC: $347.235: 349.4$

\begin{abstract}
For a longer period of time land registers in Bosnia and Herzegovina do not reflect the actual situation regarding property rights. The reasons should be sought in the poor quality of and inconsistent legislation that allowed non-registered acquisition of real property rights. On the basis of such legislation earlier Yugoslav jurisprudence had permanently denied the acquisition of property rights based on the principle of trust in the land registry. A new definition of the principle of trust, which implies the protection of the rights acquired on the basis of incorrect and incomplete land registry status, was introduced with the entry into force of the new entity laws on land registry. The main intention of the legislature is reaffirmation of the land registry and its basic principles, which is a precondition for faster and easier real estate transactions. However, the new law provides for real solutions that prevent the full application of the principle of trust, which results in the adoption of different and unequal judicial decisions. The paper presents analysis of such legal solutions, also defects that generate the emergence of different concepts of law are detected, and proposals de lege ferenda are listed in order to create the legal conditions for uniform jurisprudence.
\end{abstract}

Key words: The Principle of Trust, land registry, jurisprudence, case-law

\section{INTRODUCTION}

The entry into force of the new entity laws on land registry provides for the possibility of acquiring real rights on real estate based on the principle of trust in the accuracy and completeness of land register, as well as new original methods of acquiring rights. Non-registered holders of property rights are given more responsible attitude towards their unregistered rights, and conscientious third parties are given judicial protection which they did not have. In this way, the legislator wants to force holders of unregistered real right to initiate procedures for the implementation of their rights in the land register under the threat of their loss, which should ultimately contribute to the

improvement and update of land registers. Until the entity laws on land registry entered the force, caselaw denied the possibility of acquiring property rights based on the principle of trust. This position was based on the fact that on the basis of a legal transaction one cannot acquire ownership rights to the property from non-owners, because no one can transfer more rights on the other than they have. The paper points out the reasons why the case-law permanently denied this form of acquisition of rights, while emphasizing the legislation which provided a number of non-performing and imprecise legal provisions in this regard.

\footnotetext{
${ }^{1}$ Correspodence to: Hamid Mutapčić, PhD, Assistant Professor, Faculty of Law, University of Tuzla, Bosnia and Herzegovina Phone: 0038761374484

E-mail: hamid.mutapcic@untz.ba
} 
It also points to the case-law that due to the broadly set of subject of research of subsequent acquirer of the property (in addition to examination of the land registry there was the obligation to test ownership of real estate) which virtually enabled the application of the principle of trust. However, after the adoption of the new entity laws on land registry and real estate laws, which provides for the possibility of acquiring property rights on the basis of inaccurate and incomplete land registry, the case-law has a unique position on the application of the rules on the protection of trust, thereby it endangers the safety and intensity of legal transactions of property. A similar approach in solving property disputes of this kind can be seen via the analysis of case-laws, as well as in the earlier Yugoslav jurisprudence. With reference to the general legal principle that no one can transfer more rights on the other than they have it neglects the essential difference between a derivative or derivative acquisition rights and the acquisition based on the principles of trust as original ways to acquire rights, which is one of the issues discussed in this paper.

The new real law provides for solutions that are not in the spirit of the provisions of the land registry law. In such arrangements the application of the principle of trust is relativized and it provides an opportunity for the emergence of different legal opinions, resulting in the appearance of uneven jurisprudence. The paper presents analysis of such legal solutions, their deficiencies are detected, and de lege ferenda proposals are presented with an aim to harmonize the provisions of the land registry and real estate laws, as well as to harmonize legal opinions in the application of law. Only on the basis of consistent application of the principles and norms that promote the implementation of the land register and registration of acquired rights to the property, it is possible to enhance the process of reform of land registry law, which is a precondition for faster and easier real estate transactions, as well as the overall economic development of our country.

\section{THE PRINCIPLE OF TRUST IN THE LAND REGISTRY IN THE INTERPRETATION OF EARLIER YUGOSLAV JURISPRUDENCE}

In the older case-law it was often discussed about the legal conflict between the registered and non-registered owner, with preference given mainly to nonregistered owner of the property, who had a stronger legal basis for acquisition by substantive law. This is because the acquirer, who carried out the registration of the acquired rights in the land register, had not checked the state of the property and ownership, which was considered to be careless. It follows that the older case-law did not permit the acquisition of real rights on real estate based on the principle of trust in the accuracy and completeness of the land register despite the general provisions of the Land Registration Act of the Kingdom of Yugoslavia (hereinafter: LRA KY), according to which it is considered that the true is what is registered in the land register, and that that which is not legally registered does not exist in legal terms ${ }^{2}$. This position was based on the fact that on the basis of a legal transaction one cannot acquire ownership rights to the property from non-owners, because no one can transfer more rights on the other than they have (the transferor must be the owner in order to transfer his right of ownership to the acquiring company). In the case-law the view was also presented that the provisions of the Law on Property Relations (hereinafter: LPR), which treated the institute of acquisition from non-owners, applied only to the acquisition of property rights to movables, while one could not acquire ownership rights to the property from non-owner, regardless of conscientiousness of the acquirer.

2 "By only confiding in the land registry and registration of property rights on real estate purchased, the buyer cannot be considered a stronger in right opposite the previous acquirer who owns immovable property, if it occurred on the basis for the acquisition of the ownership by adverse possession. A bona fide buyer of real estate is the person who in addition to confidence in the land registry previously established state of possession of the purchased real estate" (The Decision of the Supreme Court of Serbia, Rev. 4740/92, Vuković, S., 2003). "A person who has a legal basis for acquisition and possession of the property is stronger in law than the land registry holder of property rights" (The Decision of the Supreme Court of Vojvodina, Gž. 103/89). "When a dispute arises between two rights on the same real estate, be that real estate law and law arising from the judgment, it is always stronger the right of the one that is in the possession of the property, whereby a contractor's conscientiousness will be evaluated" (The Decision of the Supreme Court of Serbia Rev. 120/80). "For all these reasons, in the opinion of this Court, it is not proper that land registry attaches this importance, which they had previously. One should not understand that with this attitude one wants to challenge land registry significance as real estate records for our economic and legal order, but the point is that they should not be absolute and base conscientiousness solely on the trust in the land registry, in other words, do not stick to the principle of fiction of their absolute accuracy, when it denies reality "(The Decision of the Supreme Court of Yugoslavia, Rev. $315 / 73$, December $26^{\text {th }}, 1973$, The collection of court decisions, Book I, Volume I, Belgrade 1976, Decision No. 26). 
The reasons for denial of land registry real estate transactions

The reasons for this treatment of courts should be sought in the state of land registry, which did not reflect the real picture of the legal records of real estate and the rights based on real estate, as well as in nonperforming legislation that allowed unregistered real estate. However, one should not forget the case-law that due to the uneven court decisions, but also because of different interpretations of legal provisions, further contributed to the destabilization of the land registry and its fundamental principles. It is jurisprudence, due to lack of legal solutions, that from subsequent acquirers of real estate required testing of not only land registry, but also of land state property, which practically enabled the application of the principle of trust. "The parallel effect of inconsistent application of the principle of enrollment, opportunities of non-registered acquisition and determination of conscientiousness as it was built in the jurisprudence of the former Yugoslavia (conscientious was only that who researched non-registered state) inevitably resulted in outdated land registry book" (Povlakić, 2010).

For a longer period of time land registers in Bosnia and Herzegovina did not have the importance that they had under the previous LLR KY in 1930. The most common reasons for failure of registration are evasion, negligence or low awareness that exists in certain social settings. The consequence of this is the existence of incorrect (untrue) and incomplete land registry status, because persons who are not the actual owners of the property are registered as holders of rights, or rights that exist as non-registered either as a burden or restriction on a particular property are registered in the land register. Based on the current chaotic state of land registry, the case-law consciously tolerated avoidance of registry traffic, or accepted the real estate transactions, which was carried out in non-registered manner, expanding in that way the circle of exceptions to the principle of registration and the principle of trust (Matić \& Đoković, 1998).

In addition to the land register, which did not reflect the real situation in terms of rights based on real estates, the cause of non-registered real estate also lies in the fact that the provisions of the real law allowed the acquisition of real rights on real estate even without registration in the land register. The legal rules of land registry rights principle was laid down in such a way that the registry rights could only be gained with entry in the land register (LLR KY, 1930). However, the entry into force of the LPR provided the solution according to which the entry in the land register was a material precondition for acquiring rights only in the case when the real right was acquired on the basis of a legal transaction. In all other instances registration produced declaratory effect, which meant that third parties were only informed of the existence of an effective right to the property. Therefore, the acquirer had no obligation of enrollment if the right to a property was acquired on the basis of the decision of the competent state authorities, on the basis of inheritance, or by law. The identical legal solution was later taken over by the Law on Property-Rights Relations of the Federation of Bosnia and Herzegovina (hereinafter the: LPRR), and the Law on Ownership and Other Property Rights of Brčko District Bosnia and Herzegovina. With the entry into force of the new entity laws on land registry (hereinafter: LLR FBH/RS) under Article 5 stipulates the constitutive effect of registration, which means that the real property rights are acquired by registration in the land register, except in the case of inheritance. With the affirmation of the land registry and its fundamental principles legislator wants to improve the land registry system of real estate registration and property rights. However, the entity laws on real rights (hereinafter: LRR FBH/RS) provide a decision which prescribes that on the basis of a legal transaction ownership rights are acquired by registration, unless otherwise specified by the law. It follows that it is possible to acquire a real law on the property without registration in the land register, which was also the position of the previous real estate law. A critical review of the abovementioned legal arrangement is given below in the text.

\section{The research topic of conscientious acquirer of prop- erty}

The provisions of the previous law did not foresee any real solution to the facts relevant to the conscientiousness of subsequent acquirer when the same property was alienated several times, which prevented the application of the legal analogy in circumstances when the acquirer acquires the right to the property of the formal land owner. It is left for the case-law to interpret the concept of conscientiousness too widely, demanding at the same time research of registered and non-registered state of property. The obligation to research the ownership state of property came from a view that courts should prevent any form of acquisition of real rights on real estate that would exclude the existence of non-registered acquired rights. 
If it turns out that there is a non-registered right of ownership of the real estate or some other limited property right that is acquired before the disputed entry, then it would be charged with conscientiousness of subsequent acquirer, which would result in deletion of registration of his rights in favor of non-registered officials ${ }^{3}$. In the previous case-law different legal interpretations were also recorded. In some cases there was a deviation from the established case-law, and it was required from the conscientious acquirer of the property to test only land registry state. The non-investigation of possession of property conditions did not affect the conscientiousness of subsequent acquirer ${ }^{4}$.

\footnotetext{
3"The acquirer of the property shall be deemed to be conscientious if during the acquisition of a real estate convinced him/herself that the transferor is actually in possession of stolen property. It is not enough to only access to the land registry and cadastral deed" (The Decision of the Supreme Court of Vojvodina, Rev. 525/65, Orlić, M., 1980). "The buyer is obliged to check when buying not only on the basis of the land registry of who owns, but also in nature (in the field) who is in possession of the property" (The Decision of the Supreme Court of Vojvodina, Rev. 272/89, Stamenković, D., 1991). "Only bona fide acquirer of property can call him/herself to principle of trust in the public books. Bona fide acquirer of immovable property cannot be considered the one who besides land registry state has not checked also the actual situation on the ground "(The Decision of the Supreme Court of the Republic of Croatia, Gž. 351/73, Vuković, S., 2003).

4"Because in this matter there is a conflict of legal basis for the acquisition of property, the owner of the disputed plots has become the conscious buyer who first registered his/her right in the Land Register. The respondent bought the disputed plot of land from land registered owners and thus became, as a conscientious buyer the owner of the disputed plots" (The judgment of the Supreme Court of Montenegro, GZ. 304/72, Stanković, O., Orlić, M., 1999). According to the understanding that is evident in this decision the buyer has to take into account only those facts which are registered in the land register, and will be conscientious if on the basis of the land registry convinced him/herself that the seller is registered as the land owner, regardless of whether he knew or could have known that the same properties had been already acquired by another person. According to this view, knowledge of the facts that are not registered in the land register does not affect the conscientiousness of registered buyer. However, in this case it is the acquisition of a registered right due to multiple alienation of the same property. In this case the seller is the real owner of the land, which belongs to the acquisition of such derivative ways of acquiring rights. In the case of acquisition of property rights based on the principle of trust the seller is the only formal owner of the property, because the other person gained in an unregistered manner ownership rights on the same property, for example by an adverse possession (Mulabdić, S., 2007). However, had the courts comprehended the principle of conscientiousness as in the stated decision, it would be possible to provide legal protection to persons who have acquired the right to the property on the basis of inaccurate and incomplete land registry. Google translator: Prevodilačka opremaPrevodilac web lokacijaPretraživač globalnog tržišta
}

The existence of uneven court decisions adversely affected the principle of legal certainty, as one of the fundamental principles of the legal order. Therefore, there was a need that highest courts make appropriate conclusions that would serve as the criterion for a unique solution to those types of property disputes, which would contribute to the harmonization of case-law on the entire legal field of Yugoslavia. Thus, the Symposium of the Federal Court, the supreme courts of the republics and provinces, and the Supreme Military Court of Yugoslavia adopted the conclusion No. 3/86, which among other things, stated that "the buyer of real estate with his conscience in the acquisition cannot be justified only with reference to the confidence in the absolute accuracy of land registry entry, but is obliged to check the condition and ownership of real estate "(Bulletin of the Supreme Court, No. 3/86, Povlakić, 2003). The case-law did not deviate from the view expressed in this conclusion, even though the quoted conclusion was not legally binding for the courts. The subsequent case-law would show that the conclusions of the consultation of highest courts were accepted as a general rule to address this kind of ownership disputes. The conclusion itself is based on the principle of conscientiousness and honesty as the supreme principle of one legal system, defining it as a basic rule in solving these and similar cases, leading to negligence and downgrade of the principle of trust in the Land Registry.

Due to the broadly set subject of research of subsequent acquirer of real estate, the application of the principle of trust in the land register was practically impossible. If after registration of the acquired rights in the land register appears a third party with the claim that he/she owned the disputed property independently before the registration, then the conducted registration would be annulled due to negligent acquisition. Because of this perception, non-registered holders of real rights of the property were protected and unmotivated to start procedures for the registration of acquired rights, which resulted in outdated land registry.

\section{The application of the principle of trust}

In the practice of the former Yugoslavia there were also recorded different legal interpretations concerning the obligation of researching the ownership state of the property by the acquirer who relied on the accuracy and completeness of the data entered in the Land Register. 
Thus, the decision of the Supreme Court of Slovenia, which resolved in legal disputes arising as a result of the alienation of property by the spouse who was registered in the land registry as a formal trustee, preference was given to the provisions of land rights, and the principle of trust in the accuracy of the land registry, in relation to the provisions of family law, according to which the lower instance court established the nullity of the contract and registration in the land register for the benefit of a third party. Namely, the Supreme Court dealt with the case in which only one spouse was enrolled as the owner, and in the process of executive payment against the spouse the property was sold to a third party. The other spouse filed a lawsuit against the third party and the spouse with a request to annul the concluded contract on transfer of the property and establish the right of ownership of the property in his favor. The first-instance court accepted the lawsuit and thereby invoked the Law on Marriage and Family Relations in Slovenia in 1989. This court found that the mutual assets of the real estate was the subject of marital acquits and decided that the transaction and registration, which transferred a title of the disputed property to the third party, should be void. The second-instance court reversed the trial court decision and dismissed the claim of the plaintiff. The Supreme Court of Slovenia dismissed the plaintiff's appeal and confirmed the decision at second instance. Due to the importance of the aforementioned, a part of legal positions that are the content of the above decision of the Supreme Court of Slovenia are given as follows:"the said legal matter should be weighed with special care for different interests of litigants (on one side there is, of course, the protection of property interests of the injured spouse, and on the other side is the protection of the interest of the buyer who bought the real estate with confidence in the land register); if there is a conflict of regulations between the family law and the Law on Land Registry preference should be given to the Law on Land Registry to protect the efficiency and security of legal transactions as a political and legal value of higher level of importance; that with the objective reason in favor of rejection of the plaintiff's claim (the injured spouse) speaks a strong subjective reason: that the plaintiff failed to register joint ownership in the Land Registry and in that way prevented the disposal of the other spouse; the party (plaintiff) who, because of their personal inactivity and negligence did not enroll in the land registry the right that was admitted to him/ her, cannot institute a legal inadmissibility of execution in "his/her" part of the common property, and all with regard that the third party acted honestly and acquired the property in one of the ways provided by law." ${ }^{15}$ An identical legal view was taken by the Supreme Court of Montenegro in a judgment when it decided on the acquisition of ownership rights on the property by a subsequent acquirer of the property, and which relied on the accuracy of data lisated in the Land Registry. ${ }^{6}$ The research of ownership state of the property in the opinion of this court was legally irrelevant. According to this view, the acquirer is obliged to take into account only those facts which are registered in the land register, which means a person will be conscientious if, on the basis of the land registry, a person confirms that the seller is registered as the land owner, regardless of whether he/she knew or could have known that the other person has acquired non-registered real right on the same property. The consequence is the termination of previously acquired rights on the same property that is not registered in the land registry and legal protection of subsequent acquirer who relied on the accuracy of land registration.

\section{THE PRINCIPLE OF TRUST IN LAND REGIS- TER IN RECENT CASE-LAW}

With the entry into force of the new entity laws on land registry, the principle of trust in the land register was redefined in a way that conscientious acquirers of real estate is given the protection that they have not had, which deviates from the long-standing jurisprudence that used to deny permanently the application of this principle. The introduction of new original methods of acquiring rights to the property puts before the nonregistered holders of real rights on real estate obligation to have more responsible attitude towards their unregistered rights. Only with consistent application of the principles and norms that promote the implementation of the land register and registration acquired rights to the property, it is possible to contribute to the stabilization of the land register. It is on the basis of these settings that land registry in German law works flawlessly. In German legal theory prevails reasoning that the acquirer will, who relied on the accuracy and completeness of the data listed in the Land Registry and on these grounds acquired property rights, be conscientious, even when his ignorance of the existence of non-registered rights on the same property is a consequence of his/her gross negligence (Baur, 1978; Weike, 2006).

\footnotetext{
${ }^{5}$ The Decision of the Supreme Court of the Republic of Slovenia No. II Ips 253/2000, Korać, V., 2009

${ }^{6}$ The Judgement of the Supreme Court of Montenegro, GŽ. 304/72, Stanković, O., Orlić, M., 1999
} 
Although the legislator envisaged the acquisition of real rights on real estate based on the principle of trust in the land register, as well as new original methods of acquisition of rights, in the case-law can be observed continuity in the way of resolving property disputes of this kind. It can be observed from the analysis of court decisions that in the application of law is still actual to reference to the principle that no one can transfer more rights on the other than they have, which relativizes the principle of trust and effectively prevents its use. Thus, for example the decision of the Supreme Court of the Federation of Bosnia and Herzegovina points out that legal transaction, based on which one spouse disposed of marital property without the consent of the other spouse, is not valid in terms of Article 103, Paragraph 1 of the Law on Obligations, as it is concluded contrary to the imperative legal norm of Article 265 of the former Family Law of the Federation. A prudent acquirer is disabled from acquisition based on the principle of trust in the accuracy of land registry because the seller was not the actual owner of the property. It is important to note that in this case, the audit procedure in which the Court ruled on the law, which was acquired before the entry into force of the new land registry and real estate law. ${ }^{7}$ However, in practice the Croatian Constitutional Court noted the identical point of view due to the resolution of these types of property disputes and the circumstances in which the acquisition of the disputed law occurred after the entry into force of the new Law on Land Registry and the Law on Ownership and Other Property Rights of the Republic of Croatia, which foresee the acquisition of property rights based on the principle of trust in the Land Registry. ${ }^{8}$

\footnotetext{
${ }^{7}$ Notable are decisions in the case-law of the Supreme Court of Federation of Bosnia and Herzegovina that value conscientiousness and the principle of trust in a completely different manner, which presents a breakup with the recent jurisprudence (Judgements of the Supreme Court of Federation of Bosnia and Herzegovina, Rev. 530 P 006550, from February 14th, 2013, and 230 p 01519712 Rev from December 20th, 2012., Povlakić, M., 2014). Considering the fact that it is one of the highest judical instance within one entity, it is to be expected that future ownership disputes of this kind will be sloved according to the aforementioned decisions.

${ }^{8}$ The significance of the analysis of decisions of the Constitutional Court of the Republic of Croatia reflects also in the fact that legal understandings in the Croatian law, both in legislative activities and application of law, significantly influence our law. For these reasons, further in the text is given a critical overview of decisions where the principle of trust is put in the back burner, and at the same time legal understandings from these decisions are very similar to understandings that were dominant in the earlier Yugoslavian jurisprudence.
}

In these proceedings the Court was deciding upon constitutional complaints in which applicants are invited to conscientious acquisition of property rights on the basis of inaccurate and incomplete land registers. This is because the lower instance courts cancelled the registration of the acquired rights due to the nullity of the contract on the disposal of property by the spouse who is registered as the exclusive holder of the registration law. The decisions of the lower courts emphasized, as was later confirmed by the Croatian Constitutional Court, that such disposition is null and void for lack of basic contractual obligations of the seller, or the general legal principle no one can transfer more rights on the other than they have. ${ }^{9}$

In earlier reports the fact was pointed that the earlier Yugoslav jurisprudence on the same grounds permanently denied the application of the principle of trust. However, the ownership of the seller is a material assumption of valid acquisition only in cases when acquirer bases his/her rights on the right of land registry predecessor. In this case, it is the derivative or derivative manner of claiming the right. In case that the seller is not the actual owner of the property then the purchase contract will be null and void due to lack of basic contractual obligations of the seller (the right of ownership). This rule is valid without exception in this way of acquiring right. When acquiring real rights on real estate based on the principle of trust in land registry the ownership of the seller is not a condition of validity of legal business. In this case, the right of ownership is not excerpted from the predecessors' law, but is acquired according to the law. . That is why this form of acquiring real rights on real estate is one of the original ways of acquiring rights. Although there is no basis for contractual obligations of the seller, the contract will be valid. A conscientious acquirer calling on original methods of acquiring rights replaces the lack of basis of contractual obligations of the seller, which is then valid legal transaction too, regardless of the fact that the basis of contractual obligations is fundamental for the legal business as a legal basis. It is sufficient that the seller is designated in the land registry as a property owner, and needs not necessarily be its real owner, given that the legal effects of the lack of protection of confidence rehabilitate nonexistence of authorization for registry predecessor to dispose of the existing registry law.

\footnotetext{
${ }^{9}$ The Decisions of the Constitutional Court of the Republic of Croatia No.: U-III-493/2002 from October 13th, 2004 and No.: U-III-821/2007 from June 20th, 2008.
} 
In that sense, the law protects conscientious acquirer who, trusting in the accuracy of land register entry, considered that the registered predecessor was indeed the beneficial owner. Thus, the essential difference between the two ways of acquiring rights is reflected in the fact that in a derivative way of acquiring the right that the seller must be the actual owner of the land, while in the original way of acquiring rights it is enough that the seller is registered in the land register as the owner of the property and needs not to be its real owner.

The occurrence of identical understanding in recent case-law, unfortunately, is the result of decades of case-law that constantly denied this way of acquiring real rights on real estate and in this way additionally contributed to further destabilization of the land register. The interpretation of the principles of trust, expressed in case-law before the entry into force of the new land registry and statutory laws, is understandable, given that the legal provisions contained in the earlier real law allowed a legal framework for such treatment courts, due to the existence of clear and precise legal provisions that widened the range of exceptions from the principle of registration and the principles of trust, and due to the existence of legal gaps in certain areas. A typical example of the latter is the notion that appeared in the definition of the principle of conscientiousness and a subject of research of subsequent acquirer of the property, and which is the consequence of the absence of clear and precise legal provision on a very important issue. However, this practice is not acceptable, especially after a legal redefinition of the principle of trust in the accuracy and completeness of the land registry is conducted. The termination of non-registered acquired rights should be understood as a sanction to the careless and inert non-registered holders of such rights who did not require their implementation into the main land register. For these reasons, in legal disputes that are discussed and decided on a conflict between land registered and non-registered rights on the same property the courts must have in regard the intention of the legislator and the overall process of reform of land rights, whose aim is reaffirmation of the land register and the harmonization of land registry and state of a property. Bearing in mind the difference between derivative and original ways of acquiring rights, and taking into account the stated intention of the legislator, it is necessary to access the full application of the principle of trust. The Land Registry fulfills its function precisely in circumstances in which it creates the illusion of the existence of a right to the property. Only in this way it is possible to contribute to the improvement and update of land registers, which is a prerequisite not only for faster and easier real estate transactions, but also for overall economic development of a country. The reasons why the case-law still differs from the full application of the principle of trust should be sought in the legislation, which due to its poor quality and inconsistent solutions enables legal framework for such treatment courts. Although the new land registry law provides for reform solutions that promote the implementation of land registry and registration of acquired rights to the property, some provisions of LPR FBH/RS do not follow that logic and are not in the spirit of the overall reform of land registry rights. Therefore, in practice, certain ambiguities appear, which results in the appearance of different and unequal court decisions. Such legislative solutions are not acceptable, especially if one takes into account the current process of reform of land registry rights whose aim is the reaffirmation of land registry and the harmonization of land registry and ownership state of a property. Therefore, most important shortcomings of these solutions will be pointed out further in the text, and also de lege ferenda proposals will be defined in order to create legal conditions for uniform jurisprudence.

\section{A CRITICAL OVERVIEW ON A NEW LEGAL SOLUTION}

Although the new Land Registry Law in both entities provides complete protection of rights acquired on the basis of inaccurate and incomplete land registry, the entity laws on property rights provide for solutions that relativize the application of this principle, which in the application of law creates certain problems and ambiguities. In this paper the most significant shortcomings of legislation will be given.

\section{The principle of registration in the land register}

The reform of land rights in Bosnia and Herzegovina began with the entry into force of the new entity laws on land registers. Among the most significant reform solutions are the provisions of Articles 5 and 9 of these laws, which provide constitutive effect of registration, except in the case of inheritance, or acquisition based on the principle of trust in the land register, as a new original method of acquisition of property rights. 
However, a provision that stipulates registration as a material precondition of acquiring property rights is relativized with the subsequent adoption of the LPR $\mathrm{FBH} / \mathrm{RS}$, which provides that on the basis of a legal transaction ownership rights are acquired by registration, unless otherwise specified. It follows that it is possible to acquire a claim on the property without registration in the land registry, which was also the position of the previous real estate law. It is on the basis of such legal solutions that earlier Yugoslav jurisprudence permanently denied the application of the principle of trust.

It is obvious that there is a mismatch between land registry and real estate laws regarding registration as a legitimate way of acquiring real rights on real estate. "Their mutual non-compliance with regard to such essential questions as is the way, the moment, the acquisition of real rights on real estate is a systemic failure" (Povlakić, 2010). If the practice consistently applied the provisions of the land registry law, it would significantly reduce the possibility of non-registered acquisition of real property rights, and thus prevent the occurrence of legal disputes due to the acquisition on the basis of inaccurate and incomplete land registry. It is, therefore, necessary in the coming period to align the provisions of the real law with the provisions of the land registry law which stipulates the obligation of registration of the acquired rights to the property. This would prevent the occurrence of uneven practice of law since the courts applying the rules of Lex specialis or Lex posterior could give preference to one or the other draft legislation.

\section{Postponed application of the rules on the protec- tion of trust}

The final provisions of the LPR FBH stipulate that the holders of non-registered property rights are required within three years from the date of entry into force of this law (September $5^{\text {th }}, 2013$ ) to initiate the procedure for registration of property rights in respect of real estate and all changes of the same in the land registry, which means that for that period the onset of legal effects of the principle of trust is delayed. ${ }^{10}$

\footnotetext{
${ }^{10}$ Article 374 of LPR of Federation of Bosnia and Herzegovina predicts that this law will come into force on the eighth day following its publication in the Official Gazzete of Federation of Bosnia and Herzegovina. The Law was announced on August 28th, 2013.
}

It arises from the above legislative solution that any conscientious acquisition, which is based on the principle of trust in the land registry, will be conditioned. This acquisition will become final and unconditional only when the person, in whose favor the deadline is prescribed, submits an application for registration of non-registered rights on the property or fails in a lawsuit launched by the claim.

The main reason why the legislator provided this solution is protection of non-registered acquired rights on behalf of their holders. Namely, by applying the rules on the protection of non-registered trustees of real rights on real estate could lose their acquired rights. During the period of postponed application of the rules on the protection of trust, they may request registration of their rights even against the third conscientious acquirers. Therefore, every conscientious buyer, who in the period of postponed application of the rules on the protection of trust gains the right to property, must take into account the fact that there might exist a third party with the statement that he/ she acquired a real right on the same property before the contested registration, which is why there is a possibility of loss of the registered right, or its limitation to some previously unregistered right. For these reasons conscientious acquirers still must investigate not only registered, but also non-registered state of property, in order to reduce the risk of possible loss of rights.

It is expected that during the period of postponed application of the rules on the protection of non-registered trust holders will initiate proceedings for the implementation of its unregistered rights in the land registry, which could contribute to the harmonization of land registry and ownership state of property. Given that this is a very complex and long-term work, it is difficult to expect that in the above mentioned period may appear significant progress on this issue. Thus, for example in Croatian law the deadline for the delay of the application of the principle of trust lasted for ten years. Originally, this term was scheduled for a period of five years. Later this term was extended for additional five years, and it was stipulated that holders of unregistered rights to the property were required to initiate the procedure for registration of real rights on real estate before January $1^{\text {st }}, 2007$, as well as all the changes that occurred with respect to certain property (The Law on Amendments to the Law on Land Registry of the Republic of Croatia, 2001). 
The extension of this deadline for all conscientious acquirers of property also extended the period of uncertainty and risk that the registered right may be deleted due to non-registered rights on the same property, or that such a right could be limited by the weight that exists in favor of a third party. An extension of time followed because the postponed application of the rules on the protection of confidence has not yielded the expected results, and there has been no expected harmonization of land registered and non-registered legal status of the property, which is why it could not be accessed to the application of general rules on the protection of confidence (Josipović, 2005). The real property owners did not use the legal possibility to submit the deletion actions and in that way require correction of incorrect land registry entries, and in such a way protect their registered rights to the property. The legal provisions, which stipulate the postponed application of the rules on the protection of trust, not only that they did not contribute to the improvement and update of land registers, but they delayed for the same period the onset of legal effects of protection of confidence, which likely caused a delay of the onset of the positive effects of this principle to harmonize the land registered and non-registered state property. Such solutions mean a return to the earlier case-law, where the courts denied the application of the principles of trust, and thus diminished the value of the application of other principles of land rights, which resulted in destabilization of land registry and significantly hardened real estate transactions. The Law on Property Rights of the Republic of Srpska also predicted a deadline for the delay of the principles of trust for a period of three years (The Law on Amendments to the Law on Property Rights, 2011). This deadline has expired, since the Act came into force on January $4^{\text {th }}, 2009^{11}$.

\section{The application of cancellation claim against consci- entious acquirer of property}

A damaged registered right holder has the option to use deletion actions seeking deletion of an incorrect entry in the land registry, and the establishment of early land registry state that existed in his/her favor. However, when it comes to the use of these claims against conscientious acquirer, who on the basis of an incorrect entry into land registry gained the right to property, there are different legal solutions in the legal order of Bosnia and Herzegovina.

\footnotetext{
${ }^{11}$ In Article 357 of LPR of the Republic of Srpska predicts that this Law will come intoi force on the eighth day following its publication in the Official Gazzete of Republic of Srpska. The Law was announced on December $27^{\text {th }}, 2008$.
}

Although the Land Registry Law of the Republic of Srpska does not provide for the application of deletion actions against conscientious acquirer of real estate, real right of this entity provides the solution according to which the holder of a damaged registry law can within the statutory time request the cancellation not only of inaccurate registration of registry predecessors, but also all other entries arising in such a state of land registry. The existence of such legislation is the best example of the fact that for the permanent denial of the application of the principle of trust in the Land Registry is responsible not only jurisprudence, but also the legislator who predicted a series of poor quality and inconsistent legislation. This legal decision is a step backwards and presents a return to the solutions that existed before the adoption of the new entity laws on land registry, which cannot contribute to the ongoing process of reform in the area of land registry rights. It is obvious that the legislator's real attempt to reconcile the rights of different concepts of land registry and real estate laws has failed, which can generate the emergence of different attitudes in the future jurisprudence. "In addition, the question again arises, what is it that the legislation of Bosnia and Herzegovina wishes to: Is it a land registry whose data all can trust to or is this such a type of land registry that still puts conscientiously acquisition under question mark" (Heljić, 2006).

In the legislation of the Federation of Bosnia and Herzegovina there is no non-compliance of provisions of the land registry and real estate laws regarding the application of deletion actions against conscientious acquirer of the property. A cancellation claim can be raised only within deadlines in which one can pursue challenge of the legal basis of entry of registry predecessor, but it cannot be raised if the conscientious third person, trusting in the land registry, enrolled their right.

\section{CONCLUSION}

The application of the principle of trust in the previous case-law was disabled due to a broadly set subject of research of subsequent acquirer of the property. In the absence of a legislative solution courts have demanded investigation of possession of the land registry and state of the real estate, in order to convince the acquirer that on the same property there is no nonregistered acquired right for the benefit of another person. 
Such practices threatened the safety and intensity of real estate transactions, which has destabilized the land registry and its fundamental principles. The reasons for the permanent denial of the principle of trust in the land registry should be sought in poor quality and inconsistent legislation which has widened the range of exceptions to the principle of registration and the principle of trust. In such a legal framework, the courts have consistently applied the legal principle that no one can transfer more rights on the other than they have, although this case is the original manner of claiming the right in which a basis of the contractual obligation of the seller is not a general condition for the validity of a legal transaction.

The entry into force of the new entity laws on land registry provides for the possibility of acquiring real rights on real estate on the basis of inaccurate and incomplete land registry. The main intention of the legislature is a reaffirmation of the land registry and its basic principles, which is a precondition for faster and easier real estate transactions. However, the entity laws on property rights provide for solutions that enable the acquisition of the rights to the property and no registration in the land registry, which was the position and the previous real estate law. It also requires solutions that delay the onset of legal effects of the principle of trust in a way that lays down a deadline by which holders of unregistered property rights can without limitations start procedures for the registration of their rights. The Law on Real Property Rights of the Republic of Srpska envisaged the possibility of using deletion actions against conscientious acquirer of the property, which is the most striking example that for the permanent denial of the principles of trust responsible is not only jurisprudence, but also the legislator who predicted a series of poor quality and inconsistent solutions. Such legal solutions generate the appearance of uneven jurisprudence, which endangers the principle of legal certainty as one of the fundamental principles of the law of Bosnia and Herzegovina. Therefore, it is necessary to work on amendments of the entity laws on property rights and to align these provisions with the provisions of the land registry law.

The possibility to apply for the implementation of unregistered right in the land registry by non-registered titular also exists in the circumstances of the application of general rules on the protection of confidence. Of course the grounds for such a request would depend on whether the already performed legal effects of the principle of trust in favor of conscientious acquirer of the property took part or not. If a consci- entious acquirer acquired a registered right based on this principle, the actual owner would lose their right, and the rights, burdens and restrictions that existed without registration on such properties would cease to exist. We believe that only in such circumstance would non-registered holders be encouraged to initiate procedures for the registration of acquired rights.

\section{REFERENCES}

Baur, F. (1978). Lehrbuch des Sachenrechts. München. 145. Bilten Vrhovnog suda Bosne i Hercegovine (1986). $3 / 86$.

Heljić, T. (2006). Značaj načela upisa i javnog povjerenja u zemljišnu knjigu shodno novom zemljišnoknjižnom pravu u Bosni i Hercegovini. Zbornik radova Aktualnosti građanskog $i$ trgovačkog zakonodavstva i pravne prakse. Mostar. 457.

Josipović, T. (2005). Izvanknjižno stjecanje i prestanak stvarnih prava na nekretninama. Narodne novine. Zagreb. 2223.

Korać, V. (2009). Pouzdanje u katastar nepkretnosti i raspolaganje zajedničkom imovinom. Pravni život 11. Beograd. 654-655.

Matić, D., and Đoković, T. (1998). Zemljišnoknjižni postupak. Pravni fakultet Beograd. 7-8.

Mulabdić, S. (2007). Sticanje prava vlasništva na nekretnini polazeći od načela povjerenja $u$ istinitost i potpunost zemljišne knjige. Pravna misao broj: 7-8/2007. 32.

The Decision of the Constitutional Court of the Republic of Croatia (2004). U-III-493/2002.

The Decision of the Constitutional Court of the Republic of Croatia (2008). U-III-821/2007.

The Decision of the Constitutional Court of Bosna and Herzegovina (1988). Rev. 26/88

The Decision of the Constitutional Court of the Republic of Croatia (1990). Rev. 1816/89

Orlić, M. (1980). Savesnost pri sticanju nepokretnosti. Pravni život broj: 2/1980. 74 .

Povlakić, M. (2003). Novo zemljišnoknjižno pravo. Pravni fakultet. Sarajevo. 49.

Povlakić, M. (2010). Načelo upisa i stjecanje prava vlasništva na nekretninama prema novom zemljišnoknjižnom i stvarnom pravu u BiH. Godišnjak Pravnog fakulteta $u$ Sarajevu. Pravni fakultet Sarajevo. 322.

Povlakić, M. (2010). Načelo upisa i stjecanje prava vlasništva na nekretninama prema novom zemljišnoknjižnom i stvarnom pravu u BiH. Godišnjak Pravnog fakulteta $u$ Sarajevu. Pravni fakultet Sarajevo. 248.

Povlakić, M. (2014). Načelo povjerenja u zemljišnu knjigu u najnovijoj praksi Vrhovnog suda Federacije BiH. Nova pravna revija. Sarajevo. 41-50.

The Judgment of the Supreme Court of the Federation of Bosnia and Herzegovina (2013). 650 P 04969112 Rev.

The Decision of the Federal Supreme Court (1957). Gz. 6/57. Zbirka sudskih odluka, Knjiga II, Sveska I. Beograd. 156.

Stamenković, D. (1991). Priručnik za upise u zemljišnu knjigu i katastar nepokretnosti. Savremena administracija. Beograd. 59. 
Stanković, O., Orlić, M. (1999). Stvarno pravo. Pravni informator. Beograd. 1999. 538.

Vuković, S. (2003). Sudska praksa iz svojinskopravnih odnosa. Poslovni biro. Beograd. 248, 264. Weike, J. (2006) Značaj načela upisa i javnog povjerenja u zemljišnu knjigu shodno novom zemljišnoknjižnom pravu u Bosni i Hercegovini. Zbornik radova Aktualnosti građanskog $i$ trgovačkog zakonodavstva $i$ pravne prakse. Pravni fakultet Sveučilišta u Mostaru. 447.

The Conclusion of Consultations with civic and civil commercial divisions of the Federal Court, the Supreme Military Court and the Supreme Courts of the republics and provinces (1986). 2/86.

Zakon o izmjenama i dopunama Zakona o zemljišnim knjigama Republike Hrvatske (Narodne novine broj: 114/01). Zagreb, 2001. čl. 2.

Zakon o izmjeni i dopuni Zakona o vlasništvu i drugim stvarnim pravima Republike Hrvatske (Narodne novine broj: 114/01). Zagreb, 2001. čl. 2.

Zakon o obligacionim odnosima (Službeni list SFRJ broj: 29/78, 39/85, 45/89, 57/89, Službeni list RBiH broj: 2/92, 13/94 i Službene novine FBiH broj: 29/03). Beograd, 1978.
Zakon o stvarnim pravima Federacije $\mathrm{BiH}$ (Službene novine FBiH broj: 66/2013). Sarajevo, 2013. čl. 53. st. 1., 56. st. 3., 361. st. 1.

Zakon o stvarnim pravima Republike Srpske (Službeni glasnik RS broj: 124/08, 58/09 i 95/11). Banja Luka, 2008. čl. 56. st. 3., 357., 361. st. 1.

Zakon o vlasništvu i drugim stvarnim pravima Republike Hrvatske (Narodne novine broj: 91/96, 68/98, 137/99, 22/00, 73/00, 114/01, 79/06 i 141/06). Zagreb, 1996. čl. 122. st. 1.

Zakon o zemljišnim knjigama $\mathrm{FBiH}$ (Službene novine FBiH broj: 58/2002). Sarajevo, 2002. čl. 9.

Zakon o zemljišnim knjigama Kraljevine Jugoslavije (Službene novine Kraljevine Jugoslavije broj: 146-LIII, 281-XC). $\S 4$. st. 1 .

Zakon o zemljišnim knjigama Republike Hrvatske (Narodne novine broj: 91/96, 68/98, 137/99, 73/00, 114/01 i 100/04). Zagreb, 1996. čl. 8. st. 2., 224. st. 2.

Zakon o zemljišnim knjigama RS (Službeni glasnik RS broj: 74/02). Banja Luka, 2002. čl. 9. 